\title{
THE CONSTRUCTION OF THE MALAY HERO AS CONCEIVED IN HIKAYAT HANG TUAH
}

Rahmah Bujang

rahmah@um.edu.my

Academy of Malay Studies

University of Malaya

\begin{abstract}
This article is an exposition of the legendary character of Hang Tuah in the traditional Malay literary work titled Hang Tuah edited by Kassim Ahmad (1964), which is based on the manuscript Hikayat Hang Tuah from the collection of Dewan Bahasa and Pustaka. It traces the experiences of Hang Tuah, the main character, focusing on the development of his heroism. The concept of the construction of a hero is based on Joseph Campbell's prototype model of the hero, whereby in his book The Hero with a Thousand Faces (first published 1949, third edition 2009), he summarizes every step of the hero's journey into three stages: departure, initiation and return. The objective of the article is to examine Hang Tuah as a heroic figure using Campbell's model as an archetype. The analysis will show the similarities in the treatment of the hero entity as an extraordinary person in Malay literature, while at the same time highlighting the most noticeable differences. The backbone of the construct is the contention that Hang Tuah's heroism runs in tandem with the concept of king and kingdom in Malay tradition.
\end{abstract}

Keywords: Hang Tuah, legendary warrior, Malay hero, hero's journey

\section{INTRODUCTION}

This article seeks to investigate the hero characteristics as conceived in Hang Tuah, the legendary warrior of the book Hang Tuah, a traditional Malay literary text. The earliest written version of this legendary biography is in a 
manuscript written in the Jawi script and dated 1908. ${ }^{1}$ This paper is based on Joseph Campbell's The Hero with a Thousand Faces, first published 1949, third edition $2009,{ }^{2}$ wherein he constructs a prototype or model that serves as an archetype on which something is based. The character archetypes listed in his book derive from and are deeply rooted in the myths and legends of many cultures. A significant character's role can often be associated with one of these archetypes, because storytelling is as old as these myths and legends and is how they were handed down to us. Archetypes connect one's story to the rich heritage of all storytelling (http://www.svsoft.com/Archetypes, $\% 20$ Myths\%20and\%20Characters.htm). Campbell used the work of early 20th century theorists to develop his model of the hero (see also structuralism), including Freud (particularly the Oedipus complex), Carl Jung (archetypal figures and the collective unconscious), and Arnold Van Gennep (the three stages of The Rites of Passage, which was translated by Campbell into Departure, Separation, and Return). Campbell also looked to the work of ethnographers James Frazer and Franz Boas and psychologist Otto Rank.

Campbell called this journey of the hero the monomyth, a term he borrowed from Joyce's Finnegans Wake. Campbell was a noted scholar of James Joyce (in 1944 he co-authored A Skeleton Key to Finnegans Wake with Henry Morton Robinson). In addition, Joyce's Ulysses was also highly influential in the structuring of The Hero with a Thousand Faces (http:// en.wikipedia.org/wiki/The_Hero_with_a_Thousand_Faces).

\section{THE CONCEPT OF HERO}

The concept of "hero" is always associated with bravery and courage, especially in fulfilling a higher purpose in life, or in attaining a noble end. In the West, heroism is when a literary person's journey starts after his death, and reflects certain archetypal ideas derived from Jungian psychology as well as from sociological and cultural analysis by researchers like Joseph Campbell. Jung speaks of archetypes in terms of dreams; drama is a way for the community to work out these archetypes in public ritual. For that matter, film in particular has much in common with dreaming, and many science-fiction films live out the ritual for the audience. Joseph Campbell sees the tales we tell as being shaped around certain central motifs - repeated patterns indicating deeper psychological needs and beliefs. He states that in our mythology, the hero succeeds by being reborn, which can be taken literally in some myths, or as a metaphor for necessary change-for the 
reconciliation of opposing forces within the hero. The opposing forces of life and death are what are normally reconciled in the hero. A hero must already be dead before his heroism can progress.

The literary perception of heroes is how the oral and written expressions of people points out his or her life. The hero as a literary figure undergoes some sort of ordeal in life. Most important is that he must be mortal, must undergo suffering, and, significantly, must die. Only after death can the character's heroism be immortalized, and his glory and fame be told in literary expressions such as songs, drama or storytelling. These serve as honours since death is everlasting, and for that reason these are the way the hero is immortalized, and lives on forever. Everywhere, no matter what the sphere of interest (whether religious, political, or personal), the really creative acts of heroism are presented to the world as those deriving from some sort of dying; and what happens in the interval of the hero's nonentity, so that he comes back as one reborn, made great and filled with creative power (Campbell, 35-36). Every nation, therefore, has a need to project heroes and heroism, and has conceived great literatures throughout the ages transcending time and place by virtue of the specific constructs within the psychological, sociological and cultural archetypes of each nation's religious, political and national goals and requirements.

The concept of hero can be found in the character portrayal of Hang Tuah in the Hikayat Hang Tuah in the span of his time of service to the Malay king of Melaka. The essence of the hero in the literature is a mythic construction of the character Hang Tuah, written well after his life had passed. His is a story of bravery and self-discipline bordering on self-sacrifice. His heroism comes forth as that of one who endures separation and hardship for the sake of his sovereign and country. Hang Tuah must pay a price to obtain this goal. His journey during the story is a path from the ego- the self- to a new identity, which grows as we get immersed in the experiences he has to go through in the story. Hang Tuah's chosen path consists of undergoing challenges to uphold the honour of his king. Seen within this construct, his heroism emerges in the form of facing trials and tribulations, such as separation from family and friends, venturing into an unfamiliar and challenging world as a warrior and later as a diplomat, and, finally, a return to the ordinary self in his old age. The process of becoming a hero for Hang Tuah shows in that he grows from being ordinary to being extraordinary. Often, the core of his story is not the obstacles he faces but the new valour and wisdom he acquires from a mentor, a friend, or even a villain. 
Other characters besides Hang Tuah as the protagonist may also possess heroic qualities. This is seen to be especially true of Hang Jebat, who emerges much later in the story as the antagonist. Heroes may be willing and adventurous, or reluctant. Hang Tuah is no different. Hang Tuah is never alone for he has the support of family and friends, although his family and friends may change and grow themselves, or act as catalysts for him to grow and act heroic, as is the case with his four bosom friends Hang Jebat, Kasturi, Lekir and Lekiu. The hero in Hang Tuah can be seen as an innocent, a wanderer, a martyr, a warrior, a vengeful destroyer, a leader, or a fool, but the essence of the hero is the sacrifice he makes to achieve his goal, which is to serve only his king. In this respect, other kings and rulers serve as opportunities or setbacks whom he must face and challenge in order to always make sure his king is better than all of the others.

In this paper, the construction of Hang Tuah as a Malay hero draws from Campbell who summarizes every step of the hero's journey into three stages of departure, initiation and return. According to Campbell, the three stages are as below:

\section{Departure}

The call of adventure is an aspect of departure. It is the point in a person's life when they are first given notice that everything is going to change, whether they know it or not. Often, when the call comes, the future hero refuses to heed it. This may be from a sense of duty or obligation, fear, insecurity, a sense of inadequacy, or any of a range of reasons that work to hold the person in his or her current circumstances.

However, once the hero has committed to the quest, consciously or unconsciously, his or her guide and magical helper appear, or become known. This is the point where the character actually crosses into the field of adventure, leaving the known limits of his or her world and venturing into an unknown and dangerous realm where the rules and limits are unknown - an act of crossing the first threshold. By entering this stage, the character shows willingness to undergo a metamorphosis, that is, the willingness to die.

\section{Initiation}

The road of trials is one form of initiation, a series of tests, tasks, or ordeals that the person must undergo to begin the transformation. Often, the person fails one or more of these tests, which usually occur in threes. 
According to Campbell, the meeting with a goddess is another form of initiation and it represents the point in the adventure when the character experiences a love that has the power and significance of the all-powerful, all encompassing, unconditional love that a fortunate infant may experience with his or her mother. It is also known as hieros gamos, or sacred marriage, the union of opposites, and may take place entirely within the character. In other words, the character begins to see him or herself in a non-dualistic way. This is a very important step in the process and is often represented by the character finding another that he or she loves most completely. Although Campbell symbolizes this step as a meeting with a goddess, unconditional love and/or self-unification does not have to be represented by a woman.

At one level, trial can come in the form of a temptress. This step is about those temptations that may lead the hero to abandon or stray from the quest, and as with the meeting with the goddess, does not necessarily have to be represented by a woman. For Campbell, however, this step is about the revulsion that the usually male hero may feel about his own fleshly or earthly nature, and the subsequent attachment or projection of that revulsion towards women. Woman is a metaphor for the physical or material temptations of life, since the hero-knight is often tempted by lust from his spiritual journey.

The following step occurs when the character must confront and be initiated by whomever or whatever holds the ultimate power in his or her life. In many myths and stories, this is the father, or a father figure who has the power over life and death. This is the central point of the journey. All the previous steps have been moving towards this place, all that follows will move out from it. Although this step is most frequently symbolized by an encounter with a male entity, it does not have to be a male; just someone or something with incredible power. For the transformation to take place, the character, as he or she has been, must be "killed" so that the new self can come into being. Sometimes this killing is literal, and the earthly journey for that character is either over or moves on to a different realm.

Ultimately, the goal of the quest is the achievement of the gift or boon. It is that for which the character goes on the journey. All the previous steps serve to prepare and purify the character for this step, since in many myths the boon is something transcendent like the elixir of life itself, or a plant that supplies immortality, or the Holy Grail. 


\section{Return}

The trick in returning is to retain the wisdom gained on the quest, to integrate that wisdom into a human life, and then perhaps to figure out how to share the wisdom with the rest of the world. This is usually extremely difficult.

In myth, this step is usually undertaken by a transcendental hero like Gautama Buddha. For a human hero, it may mean achieving a balance between the material and spiritual. The character has become comfortable and competent in both the inner and outer worlds.

Mastery leads to freedom from the fear of death, which in turn is the freedom to live. This is sometimes referred to as living in the moment, neither anticipating the future nor regretting the past.

\section{CONSTRUCTING THE CONCEPT OF MALAY HERO IN HANG TUAH}

Taking the above as a starting point, this paper seeks to construct the notion of the Malay hero. The figure being taken as a case in point is Hang Tuah, the legendary warrior of the early Malay Sultanate based in Melaka (English: Malacca). In the Sejarah Melayu (Malay Annals), his life encompasses the height of the Malacca Sultanate period (1456AD to 1511AD) and spans the rule of three Malay kings-Sultan Alauddin Riayat Shah, Sultan Mansor Shah and Sultan Mahmud Shah.

Sultan Alauddin Riayat Shah was well-known as a ruler who established the laws of the Melaka kingdom. During his reign, the laws of land and sea were set in place. It was the period of Hang Tuah's childhood. Sultan Mansor Shah ascended the throne after Sultan Alauddin Riayat Shah and his period of reign was the peak of the civilization of the Malay sultanate. With the legal aspects in place, the king could carry out his duties fairly and according to the laws of the land. It was also an opportune situation for him because Hang Tuah had grown into a strapping young warrior respected by his friends and feared by his foes. In the book of Hang Tuah, the main character, Hang Tuah, had four supportive warrior friends to give him added strength-Hang Jebat, Hang Kasturi, Hang Lekir and Hang Lekiu. According to the text of Hang Tuah, Sultan Mahmud Shah, the last king of Melaka, is said to have given over his reign to Puteri Gunung Ledang, and this occurs at the twilight of Hang Tuah's life.

Putting all this aside, let us examine Hang Tuah's heroism in greater detail. Campbell's notion of the hero's journey into the sequence of departure, 
separation, and return will be used as a yardstick. Hang Tuah's journey begins with the mystique surrounding his birth. Most important in Hang Tuah's story is that he was born into a family of simple village folk but that his fate was soon to change. His father, Hang Mahmud, dreamt of the moonlight shining upon his son's forehead. In the Malay belief system, this dream augurs well for the newborn, foreshadowing greatness and fame in his future life. It is also a signal for the father, being the one who has had the dream, to act upon the omen.

Hang Tuah is divided into two sections: conflict and exploration. However, the tale that is told in Hang Tuah can be better analyzed from the basis of its main character, Hang Tuah, for the whole book focuses on the heroism of this character. As is the norm with Malay traditional literary style, the story begins with the narration of the establishment of sovereign rule. Thus, the story tells of the beginnings of a great kingdom in the region called Bukit Seguntang. Sang Sapurba, the son of a great king, Sang Perta Dewa, is blessed by the gods by being presented with a beautiful baby girl that soon grows into a beautiful maiden. The baby girl emerges from the vomit of a sacred white cow that disappears soon after. Sang Sapurba marries the girl and rules over Bukit Seguntang, and they have four handsome sons. At the beginning of the story, these sons have grown up within the kingdoms of Bintan, Singapura and Bukit Seguntang. Once the origin of the kingdom is ascertained, the story of Hang Tuah follows.

In this article, the story of Hang Tuah's heroism is analyzed according to the sequence of departure, separation, and return used by Campbell. However, the chronological development in the unfolding of Hang Tuah's story necessitates further categorization into the following time frames: youth, maturity and old age. These are analyzed below.

\section{HANG TUAH'S EMERGENCE AS A HERO}

\section{The Early Years}

1. Upon his birth, Hang Tuah's father moves the whole family from the village of Sungai Duyong to Bintan. There he sets up an eatery near the court of Bendahara Paduka Raja. This is seen as a departure from a life of nonentity into a life of opportunity, and the chance to be noticed by courtiers like the Prime Minister (Bendahara). 
2. As a child, Hang Tuah proves to be a quick learner - by the age of ten he is able to read the Quran fluently; he is able speak twelve languages; he has support in four friends of the same age: Hang Jebat, Hang Kasturi, Hang Lekir and Hang Lekiu.

3. The boat (perahu lading) his father uses for the move from Sungai Duyong to Bintan is at his disposal for youthful pastime along the waters of the region. It prepares Hang Tuah and his friends for getting used to the shorelines and sailing.

4. Their biggest achievement is wounding and capturing ten grown men who plunder the riches of Palembang via the rivers around Siantan and Jemaja on the behest of a minister named Pateh Gajah Mada, from the neighbouring kingdom of Majapahit. With the aid of a chieftain from Singapura who is travelling to Bintan on his boat, the wounded captives are brought to Bendahara Paduka Raja for justice to be served.

5. Hang Tuah and his four friends seek out a mystic named Aria Putera at Bukit Panchalusa to learn martial arts of self defence. Aria Putera also instructs Hang Tuah that when he is in Majapahit, he is to further his studies on the art of self defence from his famous brother, Sang Persata Nala.

6. Fresh from his learnings, Hang Tuah chops wood the very next morning when he confronts and kills an amok. Then, with the aid of his four friends, he kills two more, and his friends kill two between them, saving the Bendahara's life.

7. In gratitude, Bendahara Paduka Raja brings all five friends and their parents to his court (Balai Penghadapan), and honours the families with feasting and merrymaking. His son, Tun Mat, is introduced to the five boys and they become friends. Bendahara Paduka Raja and his wife become friends with the boys' parents.

8. The king of Bukit Seguntang quickly takes in the boys and presents them with new keris specially made for them, and proper attire befitting their new station as the king's Bentara.

9. Hang Tuah's initiation into royal service and life in the Malay courts begins. This is the final point of Hang Tuah's departure from country bumpkin to court official.

10. One of the first royal tasks they carry out for the king is to sail to 
Palembang in order to get rid of the pirates plaguing the shores of Siantan and Jemaja, which they successfully perform using seven rowing boats (perahu dendang) and seven sailing boats (lanchang). With these boats, Hang Tuah and his friends keep the Malay kingdom and the surrounding seas free of piracy and the country prospers.

In this segment of the story, Hang Tuah's departure from Sungai Duyong to Bintan is initiated by his father. As a young boy, Hang Tuah proves to be a quick learner. As an adventuresome lad, Hang Tuah's foray into the surrounding waters of the land is an opportunity open to him, for his father has a boat that Hang Tuah and his friends could use. Their first open battle with adults proves successful and gives Hang Tuah and his friends the incentive to go for martial arts training under the tutelage of a renowned mystic of the land. This equips him against other physical threats. It is fortunate that at one point he also saves the life of the highest chieftain of the land, the Bendahara (Prime Minister). The natural thing to do then is for the Bendahara to present Hang Tuah and his friends to the king, and thus Hang Tuah comes into the king's service.

\section{HANG TUAH'S ESTABLISHMENT AS A HERO}

\section{In the Eyes of the King}

1. The founding of Melaka is the beginning of Hang Tuah's establishment as a heroic figure in the region. Hang Tuah is instrumental in aiding the third son of the king of Bukit Seguntang to establish the new kingdom of Melaka. The king installs himself as the Ratu, and his youngest brother as the Raja Muda. Hang Tuah is instated as the chief Bentara of the new kingdom.

2. The beginnings of the kingdom of Melaka are mostly spent with Hang Tuah aiding the king of Melaka to establish diplomatic relations with other Malay kingdoms, carrying out official visits or sending letters regularly to Palembang, Bintan, Gagelang, Bukit Saguntang. Among the customs of the time was the presenting of state gifts and groups of select people to serve the king in his new kingdom. Soon the kingdom flourishes and more people are attracted to come to stay or trade in Melaka. However, a group of people defames the Raja Muda 
by reporting to the king that he has taken up with bad company to strengthen his position in the kingdom. This leads to his being deposed by the king, his brother.

3. However, the Raja Muda's fortune lie someplace else, for a rich and powerful merchant, Parmadewan, has heard about him and wants him to become king of the country of the Keling (in India). Hang Tuah is given the job of training the young prince on the art of being a good king. Between the Bendahara and Hang Tuah, they manage to win over the king, the Yang Di Pertuan of Melaka, to approve his brother's newfound status, thus realizing the greatness of all four sons of Sang Sapurba.

4. The Ratu of Melaka hears of the beauty of Tun Teja, the daughter of Bendahara Seri Buana of Inderapura. He desires to take her as his wife. Tun Teja refuses, reasoning on the difference of status between her and the king. The king is of too high a status, being royalty descended from the heavens (keinderaan), whereas she is only a commoner (keluaran). Tun Utama and Tun Bija Sura, the two courtiers sent to seek her hand in marriage, return with the news of their unsuccessful effort, making the king feel very sad indeed. Hang Tuah's response to the failed attempt shames the two chieftains when he exclaims that he would have executed such a decree to success even if it cost him his life. ("Cheh! Bukan orangnya yang dititahkan itu. Jika Si Tuah gerangan membawa titah tuannya, sehingga putih tulang tiada putih mata." : Hikayat Hang Tuah; page 94).

5. It is suggested that the king ask for the hand of an equally-beautiful Javanese princess in Majapahit, and the king is agreeable to the idea. This time, Hang Tuah offers himself to be the emissary together with Pateh Kerma Wijaya and his four friends for the mission. Hang Tuah vows to the king that he will not return unless successful in his quest.

6. After much trial and tribulation in Majapahit, Hang Tuah's mission is successful and the Ratu of Melaka marries Raden Galuh Mas Ayu, the only child of Betara Majapahit, the king.

In this segment, Hang Tuah's worth becomes established in the eyes of the king of Melaka. All the service Hang Tuah gives is for the ultimate fulfillment as the servant of the king. This is also the segment wherein Hang Tuah's heroism is tested from a higher order in the person of Pateh Gajah Mada, the highest chieftain (Prime Minister) of the Majapahit kingdom. The 
marriage between the king of Melaka and the king of Majapahit's daughter and his only heir was seen by Majapahit as a means of gaining supremacy over the Malay kingdom. However, Hang Tuah serves as the stumbling block to Majapahit's wish to have control over Melaka. Therefore, Pateh Gajah Mada takes it upon himself to try, by hook or by crook, to oust Hang Tuah; but all his efforts are in vain.

\section{JEALOUS COURTIERS VERSUS HANG TUAH}

\section{Rivalry and Opposition at home}

1. In Melaka, Hang Tuah rises in favour in the eyes of the king. However, such favour is marred by the jealousy of the chiefs of the Malay court who decide to turn the tables on him by telling slander about him to the king of Melaka. Leading the slanderous pack is Pateh Kerma Wijaya. They tell the king that Hang Tuah has been seen to take advantage of his position by freely going into the royal household and having an affair with one of the king's concubines. Hang Tuah is stripped of his office, and decides to let things cool off. He sets sail for Inderapura on his own. There, he takes refuge with Bendahara Seri Buana, Tun Teja's father. With his ability and cunning he manages to beguile Tun Teja, now unwillingly engaged to Megat Panji Alam of Terengganu, into following him to Melaka. Hang Tuah brings Tun Teja to present to the Melaka king. Under the influence of Hang Tuah's magic potion, the beautiful but proud Tun Teja falls in love with him and goes with him to Melaka. Under the influence of another magic potion, she falls out of love with him and willingly accepts to become the wife of the Melaka king. Megat Panji Alam's attempt to avenge the loss of his fiancée ends in his death at the hands of Hang Tuah and Hang Kasturi. Hang Tuah is once again in the king's favour. The king rewards Hang Tuah by conferring on him the title of Laksamana.

2. Jealousy with regard to Hang Tuah's favoured position rears its ugly head once again. The same ploy is used against him, and the king falls for it a second time. Like the first time, the mastermind behind the treachery is Pateh Kerma Wijaya. The jealous courtiers accuse Hang Tuah of tainting the king's household by having secret meetings with one of the ladies in the king's household. This act is considered tantamount to treason. The accusation, when brought to the knowledge of the king, vexes him so much so that he immediately orders Hang Tuah's execution, handing the undesirable task to his Bendahara. 
Hang Tuah decides to agree to the Bendahara's plan to make the trek to the edge of the Melaka kingdom - seven days and seven nights away. There, Hang Tuah spends his idle days under the tutelage of a religious teacher named Sheikh Mansur. Much to his delight, he hears from the Sheikh that Melaka in his absence is not the same. For, indeed, as soon as the king had passed his sentence, he became morose and dejected from the loss. He kept to his quarters for seven days. Only Hang Jebat's beautiful storytelling finally please the king so much that he showers Hang Jebat with kindness. He summons Hang Jebat to his court to listen to him and have Hang Jebat lull him to sleep by singing to him while he is lying on Hang Jebat's lap. The king even bestows upon him the title Paduka Raja (king's close aide), and gives him Hang Tuah's keris, Taming Sari, as a gift. However, Hang Jebat is scheming to avenge the wrongly-punished Hang Tuah. He has his way of punishing the jealous courtiers. He capitalizes on the present mood of the king and allows no one to come and have easy access to the king. Given such free access in and out of the king's household, Hang Jebat soon finds himself living like a prince. He likes his new lifestyle so much that soon he resides full-time in the palaces of Tun Teja and Raden Mas Ayu. The situation becomes unbearable for the king and he takes his family into the sanctuary of the Bendahara's court but all efforts to oust Hang Jebat from the palace prove futile. Upon the king's lamentation about his sinning against Hang Tuah, and seeing the king transferring his love of Hang Tuah upon Hang Tuah's son, Hang Nadim, whom the king takes as his own, the Bendahara finally relents and reveals the truth about what he did with Hang Tuah. Thus, Hang Tuah is recalled from banishment, prepared for battle (for he had left off all physical conflicts and warfare in the previous four months), and on a day of his choosing, Hang Tuah confronts Hang Jebat. The duel that ensues between Hang Tuah and Hang Jebat is long and hard. They duel with their keris as weapons and confine their duel within the walls of the palace. Hang Tuah knows that Hang Jebat can never be killed as long as he has Taming Sari in his hands. At an opportune time, he manages to grab the keris that was rightly his; and gives Hang Jebat his Parung Sari. The duel ends with Hang Tuah thrusting Taming Sari right through Hang Jebat's chest. It takes Hang Jebat a whole night and a day to die, and he wreaks havoc by running amok and killing everyone in his path.

3. Once again Hang Tuah proves invaluable to the kingdom of Melaka. His sacrifice for the king is a hard one. He acts with wisdom to help others wrongfully sentenced by his king but is also the first to unquestionably 
accept any punishment meted out upon him by the king. Anyone lesser than him would have failed as a man. Hang Jebat, who has arisen as the anti-hero, was indeed proven the lesser man, although ironically his downfall was to avenge Hang Tuah's wrongful punishment. Hang Tuah, however, has become wiser upon his banishment in the seclusion of the backwaters of Melaka; for there he mastered religious learning under Sheikh Mansur. Also, although Hang Jebat was killed by Hang Tuah, their friendship never comes to an end, and it is Hang Tuah who takes Hang Jebat's illegitimate son, Hang Kadim, and puts him in the care of Tun Teja's father in Inderapura.

Although chronologically this does not come in the correct order, it is important to group this under the issue of "jealous courtiers of Melaka". It also serves as proof of Hang Tuah's resilience and helps establish his initiation process into heroism. We see how Hang Tuah's service to the king is put to the test not once but twice. In both cases the same ruse was used. The king's palace is regarded as a sacred sanctuary that no commoner, however high his position, should taint. Hang Tuah's closeness to the king works against him. The jealous courtiers accuse him of carrying on with the king's maidservants. Both times it is the Bendahara who saves him from the king's wrath. In the first instance, Hang Tuah retreats to Inderapura, where he uses his wiles to win Tun Teja for his king, thus gaining the king's pardon. In the second instance, he retreats to the backwaters of the kingdom, where he lives the life of a recluse, spending all his time in the enrichment of religious knowledge. His reinstatement into the king's court is ironic, for he is called back into the king's service to kill his friend, Hang Jebat, who has taken it upon himself to avenge Hang Tuah's death, and who himself has become embroiled in the situation of which Hang Tuah was accused earlier.

\section{PATEH GAJAH MADA'S VENDETTA AGAINST MELAKA AND HANG TUAH}

\section{Rivalry and Opposition Abroad}

1. The link with the kingdom of Majapahit begins when there is a need for the Melaka king to take a wife and the attempt to win Tun Teja's hand in marriage fails. Raden Galuh Mas Ayu, the only child of the Majapahit king, is suggested as the next choice. The alliance is not 
without its challenges for it becomes the obsession of Majapahit epitomized by its prime minister, Pateh Gajah Mada, to establish Majapahit's supremacy over Melaka. The exploits of Hang Tuah as a warrior are largely a way of projecting the greatness of the Melaka kingdom against its rival kingdom, Majapahit. All other countries within the region including India are ruled by descendants of Sang Sapurba, except Majapahit. Diplomatic ties between Melaka and Majapahit are achieved via marriage. Two suitors vie for the hand of the princess in marriage - the king of Melaka and his younger brother, the ruler of Keling. However, Hang Tuah manages to sway the decision in favour of his king. Hang Tuah is a symbolic extension of the power and sovereignty of Melaka. Hang Tuah's arch rival and foe is the Prime Minister of Majapahit, Pateh Gajah Mada. Pateh had all the Majapahit warriors at his beck and call, whereas Hang Tuah fought with his own might and cunning. Against Pateh Gajah Mada, Hang Tuah is undefeatable in both lands, Majapahit and Melaka. Pateh's vendetta against Hang Tuah is proof of his untiring efforts to overpower Hang Tuah so as to gain control of Melaka.

2. There are several attempts on Hang Tuah's life in the presence of the Bentara of Majapahit and the king of Melaka while at the Majapahit court. The schemer was none other than Pateh Gajah Mada. When the Melaka party are there for the marriage between their king and the princess, Pateh had his best warriors try to kill Hang Tuah - under the pretext of running amok, or planted among the guests to take Hang Tuah's weapon and shame him publicly. However, all of Pateh's ruses fail and instead Hang Tuah emerges as the hero through his valour and cunning. In one incident, he is given the keris belonging to one of the warriors who runs amok, Taming Sari; this lends him invincibility. The many bouts that he wins make him a figure to be respected in Majapahit. The Betara even honours him with the title Laksamana and bestows upon him the kingdom of Jemaja. All in all, there are five attempts made on Hang Tuah's life, three in Majapahit, and two while Hang Tuah is in Melaka; all of them masterminded by Pateh Gajah Mada.

In this segment, the story dwells on how Hang Tuah proved his heroism outside his own country. This initiation into his role as hero happens prior to the second accusation against him which leads to the loss of his friend, Hang Jebat. The main antagonism comes from none other than Pateh Gajah Mada. As Prime Minister, he has others do his dirty work for him. Many attempts 
are made on Hang Tuah's life, or at least attempts to publicly shame him. Hang Tuah, however, emerges the hero in all those attempts. Finally, even his foes come to respect and fear him.

\section{HANG TUAH'S ALLEGIANCE TO KING AND COUNTRY}

\section{Hang Tuah's Diplomacy and Diplomatic Missions}

1. Having established peace for the kingdom of Melaka, the king sees fit to have his top officials go on diplomatic missions. Hang Tuah is the logical choice, and in all his travels, Laksamana Hang Tuah always has Hang Kasturi, Maharaja Setia of the Melaka kingdom, as his partner. Hang Tuah's role as diplomat for the king of Melaka is listed in the tables below. The entourage sails in twelve sailing ships with Hang Tuah heading the royal vessel, Mendam Berahi. Hang Tuah has the good fortune of stopping by a deserted island where he is given a magical seed by a hermit at the beginning of his journey. The magical seed that once planted immediately grows and bears fruits for everyone to eat before the tree dies, helps enhance Hang Tuah's credibility in the eyes of the royals and kings of the lands he visits. Hang Tuah's fame has also preceded him and he wins hearts everywhere he goes. Through the diplomatic missions, great success is achieved in the enhancing of good relations between kingdoms, and with it great wealth and fortune were derived from the gifts or trading between kingdoms.

2. Hang Tuah is first sent to the Keling kingdom to bring news from the kin of Melaka to his brother, Kisna Rayan, the king of Bijaya Nagaram. From there, he goes on to China. At another time, he goes to Berunai and Siam. He was also deployed to Europe to purchase firearms from the Roman Empire. Hang Tuah stopped by the Middle East and performed the pilgrimage, to fulfill his obligation as a Muslim. In his travels, the Portuguese were seen to be envious of the status and honour accorded him.

Hang Tuah would do anything and everything for his king. In Hang Tuah, his heroism extends to other matters beside warfare.

3. He is the only warrior who succeeds in getting the fruit that was 
desired by Raden Galuh from a special coconut tree, known for its great height and midway-rotten trunk.

4. He is the only one willing to save the horse of the king's son when it falls into a cistern full of human excrement.

5. Hang Tuah is the one chosen to bring Raden Bahar, the king's eldest son and grandson of Betara Majapahit, to Majapahit to be installed as the new Bentara upon the grandfather's demise.

6. Hang Tuah takes it upon himself, while still alive, to be given the rites as of one who has died, to be able to return to tell his king what happens in the world of the dead; because that is the king's wish.

Even in his advanced age, Hang Tuah manages to ward off the first Portuguese attempt to invade Melaka, by maiming their base at the Philippines and killing their Filipino allies which makes them retreat to Portugal.

In a land bordered by seas, a hero's work is never done unless he has plied the oceans. What better way to do this than to see him succeed as his country's emissary and representative of the king in forging good relations with kings of other countries. This becomes Hang Tuah's journey in life after the Malay kingdom has gained peace and prosperity.

\section{HANG TUAH'S TWILIGHT YEARS}

\section{A Hero's Work is Done}

1. Hang Tuah's life-journey as a warrior and hero begins to end was when he loses his keris, Taming Sari, while saving his king's crown that fell into the sea. The royal party is holidaying off the island of Singapura when this happens. Just as Hang Tuah emerges from beneath the sea with the king's crown in one hand and his keris in the other, a ferocious white crocodile suddenly snatched his weapon and dives into the sea's depth, with Hang Tuah hanging on to his tail. The crown is lost. Hang Tuah manages to come back to safety but his keris is lost.

2. Then, Hang Tuah's benefactor, Bendahara Paduka Raja, dies; and although another Bendahara is installed to replace him, Hang Tuah has lost a staunch friend and ally. 
3. Soon after, the king himself installs his youngest child, a daughter named Puteri Gunung Ledang, as the ruler of Melaka, sheds off all his worldly belongings, lives his life as a hermit, and travels the land as an ascetic. $\mathrm{He}$ is never heard of again.

4. Hang Tuah himself retreats to Tanjung Jugara, where he spends his final days committed to religious piety. It is also about this time that the Portuguese invade again, and this time succeed in taking over the kingdom of Melaka.

All good things must end. A hero's journey must come to a point of no return. In Hang Tuah's case it is reaching old age. The real return to the ordinary and into a life of solitude for him, however, is epitomized by the decision of his king to lead the life of an ascetic. Thus Hang Tuah's heroic adventure ends when his king chooses to free himself from his kingship.

\section{FORMULATION OF HANG TUAH'S HEROISM}

We can formulate the hero concept vis-à-vis Hang Tuah within the construct used by Campbell into departure, initiation and return. Yet, in Hang Tuah we find a specific difference in its fulfillment. Salient aspects of the categorization put up by Campbell exist but the fulfillment is different, as shown below:

\section{Departure}

The call to adventure for Hang Tuah as a point of departure in his life is when his father relocates the whole family from their place in Sungai Duyong, a more inland village area, to Bintan, where the Bendahara (Prime Minister) of Bukit Seguntang holds court. The move was given impetus by the dream that foreshadows a great future for his son, Hang Tuah, and therefore calls for change. The call for change is associated with being near the ruling class of society. In their new surroundings, Hang Tuah grows up with the opportunities available within such a neighborhood. Hang Tuah excels in his education; in the learning of languages and religious teachings. In youth, Hang Tuah has the stable company of friends in Hang Jebat, Hang Kasturi, Hang Lekir and Hang Lekiu, and the five of them are courageous, adventurous and full of heroic spirit. As youths, they are able to venture upon the waterways and surrounding seas because Hang Tuah's father has a boat that is their mode of travel in the departure to change of place. 
However, once the hero in Hang Tuah is established, the next step is what or who enhances his ability. The benefactor is Bendahara Paduka Raja, who promptly presents him and his four friends to one of the four princes of the Sang Sapurba kingdom. The prince goes on to establish a new kingdom in Melaka, and Hang Tuah emerges as a prominent member of its leadership. This is the point where Hang Tuah's life changes forever. It is the point of separation from the hero's known world and self to a new world and new potential for himself. It is a world that offers Hang Tuah metamorphosis from village bumpkin to courtier. Hang Tuah is not one to be satisfied with his current situation, and so he begins to enhance his position by gaining experiences that will shape his new world and self, mainly by seeking knowledge in the ways of a warrior from Aria Putera, who tells Hang Tuah also to learn from his famous mystic warrior brother, Sang Persata Nala, which Hang Tuah then does.

\section{Initiation}

Hang Tuah's road of trials in upholding his status as the king's aide is his form of initiation. He proves himself able to rise up to any task or ordeal that he must undergo to begin to make his presence felt before the king. Royal recognition is therefore his means of transformation from humble citizen to dignified courtier. The gift of Taming Sari, a magical keris which Hang Tuah won in combat against its owner, completes the transformation; for Taming Sari makes its owner invulnerable. Owning Taming Sari is Hang Tuah's establishment into the world of heroism for every foe he confronts, in spite of strength or number, will finally yield to his might or cunning.

If Hang Tuah's biggest supporter is the Prime Minister of Melaka, Bendahara Paduka Raja, Hang Tuah's biggest enemy comes in the form of another Prime Minister, Pateh Gajah Mada of Majapahit. The latter's goal is to put Hang Tuah, the hero, to shame before the eyes of the kings, the Yang Di Pertuan of Melaka and the king's father-in-law, the Seri Betara of Majapahit. Pateh Gajah Mada, however, is the cause of Hang Tuah's ultimate initiation into invulnerability, for it is unwittingly due to him that the keris of Taming Sari comes into Hang Tuah's ownership.

Hang Tuah rises to a position of privilege at the court of the king. From the position of Bentara, king's man, Hang Tuah rises to the final position of Laksamana, which is the third-highest in the land after Bendahara and Temenggung. Hang Tuah, as the king's closest aide and ally, is treated 
almost on equal footing by the king. As much as the king would look to Hang Tuah for advice or fulfillment of tasks, Hang Tuah would be there first and foremost for his king. This situation poses yet another challenge to Hang Tuah, the challenge of jealousy among the courtiers, especially those that found themselves belittled in the process of Hang Tuah's rise to fame. However, true to the fortune foretold at his birth, even in banishment from the court, Hang Tuah gained more by having time off to gain deeper religious knowledge for his spiritual self. His triumphant return to the Melaka court comes to a climax with the killing of the traitor to the king, Hang Tuah's close friend Hang Jebat.

The crown of Hang Tuah's achievements is leading diplomatic missions as the representative of his king. This is the main role that the hero, Hang Tuah, plays for his king and country. It brings him fame, for, other than fulfilling his role as his king's spokesperson, he gained personal contact with the kings of all the lands that he visited. They were all impressed with Hang Tuah's ability and might.

\section{Return}

The words of the king of Melaka are relayed by Hang Tuah everywhere he goes. Yet, the king requires more of Hang Tuah. He wants to know what happens to someone in death. A most abnormal request, indeed, but one not to be refused by Hang Tuah, who agrees to go through the rites as of someone dead and is buried. He comes back with proof of what could happen. Perhaps this final service by Hang Tuah made the king realize his actual status before God and humbled him into leading the life of an ascetic. Now without the king whom he has served all his life, Hang Tuah, too, decides to return to a life committed to prayer and religion.

In his lifetime, Hang Tuah leads a charmed life, loved by his king, revered by all men, respected by friends and feared by his foes. His is an adventurous journey, starting at the tender age of ten years. His life is not without its dangers and trials but Hang Tuah copes with it, or escapes and rises above it all. Just as the hero may need guides and assistants to set out on a quest, so does Hang Tuah; for he always has his four close friends to support him and be by his side. He also has the patronage of the Bendahara Paduka Raja. Thus, Hang Tuah keeps returning to the life destined for him at the right time and place, enabling him to integrate his life into one of valour and wisdom. In truth, Hang Tuah's journey is legendary and oftentimes mythical, 
which, for a human hero such as him, means achieving a balance between the material and spiritual. The person inside him has become comfortable and competent in both the inner and outer worlds.

Control and mastery of his life leads to freedom even from the fear of death, which in turn opens up his freedom to live; something that is referred to as living in the moment, neither anticipating the future nor regretting the past.

\section{CONCLUSION}

In Malay literature, Hang Tuah is a symbol of heroism. One very basic difference concerning Hang Tuah's heroism as compared to that of the heroes of the Western tradition, as analyzed by Campbell, is that in the text of Hang Tuah, it is the self-made strength and courage of the man in Hang Tuah that comes forth. Hang Tuah has two father-figures to guide him on his path of life, one in his biological father, Hang Mahmud, and the other his socio-cultural father, the Bendahara of Melaka. However, Hang Tuah's destiny is of his own making. His is the story of heroism borne out of the single-mindedness of a man wishing only to be a good servant to his king. Another difference is that Hang Tuah's courage and valour is that of an ordinary man (in contrast to the demigod or god-like heroes of Western tradition) but one who has attained a high status and esteem for his steadfast commitment to his king, and his steadfast belief in his God through his spiritual immersion in his religion. The mythic quality of Hang Tuah the man lends a new dimension to the global concept already put forth by Campbell.

\section{NOTES}

1 Kassim Ahmad, Hikayat Hang Tuah; 1964, p. xvi.

2 The book was originally published in 1949 by Pantheon Press as the seventeenth title in the Bollingen Series. This series was taken over by Princeton University Press, who published The Hero through 2006. The Hero with a Thousand Faces has been reprinted a number of times. Princeton University Press issued a commemorative printing of the second edition in 2004 on the occasion of the joint centennial of Campbell's birth. The third edition, compiled by the Joseph Campbell Foundation and published by New World Library, was released as the twelfth title in the Collected Works of Joseph Campbell series in July 2008. 


\section{REFERENCES}

Cheah Boon Kheng, 1998. Sejarah Melayu. Malaysian Branch Royal Asiatic Society.

http://www.svsoft.com/Archetypes, \%20Myths\%20and\%20Characters.htm $\mathrm{http} / / /$ en.wikipedia.org/wiki/The_Hero_with_a_Thousand_Faces

Kassim Ahmad, 1964. Hikayat Hang Tuah. Kuala Lumpur: Dewan Bahasa dan Pustaka.

Joseph Campbell Foundation, 2008. The Hero with a Thousand Faces. (Collected Works of Joseph Campbell Series). California: New World Library.

Morton A. Kaplan (ed.), 2000. Character and Identity: The Sociological Foundation of Literary and Historical Perspectives. Professor World Peace Academy, U.S.A.: Paragon House Publishers. 